\title{
THE MODERATING EFFECT OF KEY CUSTOMER FOCUS ON MARKET-BASDED ORGANIZATIONAL LEARNING
}

\author{
Niels Becker, RWTH University of Aachen, Germany
}

Malte Brettel, RWTH University of Aachen, Germany

\begin{abstract}
Much of the extensive market orientation literature is concerned with how companies develop their knowledge about customers and competitors. It has been argued that firms can obtain a competitive advantage by catering to specific customer needs by applying this market knowledge (Slater et al. 1994). However, recently scholars have recognized that market orientation (i.e. the gathering and internal dissemination of market information) alone might not lead to a sustainable competitive advantage (Slater et al. 1995). Instead, the importance of the organization's ability to correctly interpret market data is increasingly being recognized (Ali et al. 2010). Organizational research scholars suggest that higher-order learning is required, such that complex market information can be effectively harnessed (Morgan et al. 2003). Accordingly, the interplay of market and learning orientation, also referred to as market-based organizational learning, has received increasing research attention (Jimenéz- Jimenéz et al. 2007, Santos-Vijande et al. 2005).
\end{abstract}

A second trend in the marketing field is that scholars frequently propose that companies should focus on their most valuable customers (Zablah et al. 2004, Algesheimer et al. 2006). Particularly in the context of customer relationship management (CRM) research it is argued that based on extensive customer databases and lifetime value computations firms should focus their company resources on high value customers. This judicious resource allocation is expected to lead to superior company performance (Homburg et al. 2008, Yim et al. 2004). However, little is known about the consequences of a key customer focus on market-based organizational learning. Some researchers indicate that focusing on key customers (segments) might benefit these processes (Pelham 1997). Others, however, point out that companies should not rely on too narrow a market definition. Slater et al. (1995) e.g. critically note that focusing on specific market segments or customers "could lead to learning only within boundaries" and Hamel et al. (1991) criticize that firms might suffer from the "tyranny of the served market".

Drawing on the resource-based view the present research study addresses two areas. First, it furthers the understanding of the performance consequences of market-based organizational learning. In this regard it is assumed that in addition to the direct performances consequences of market orientation, there is also an indirect effect as learning orientation mediates the link between market orientation and company performance. Market orientation is seen as the principal foundation on which learning occurs. Market orientation thus impacts the scope of the information processing activity, whereas learning orientation influences the higher order examination of this activity (Day 1994, Sinkula 1994). Second, this research investigates the moderating effect of a key customer focus on market-based organizational learning. Focusing on key customers implies that companies build particularly close relationships with their best customers, but run the risk of not establishing close contacts with less important ones (Reinartz et al. 2004). Since close relationships are a key condition for information exchange (Bagozzi 1975, Ritter 1999), it can be reasoned that key customers drive the information gathering process and therefore exert a great influence on the selling firm's information gathering (Blosch 2000). If these target customers do not recognize a change in the market firms might forego important opportunities (Christensen 1997). This might be particularly true in dynamic market environments.

To conduct the research a cross-sectional online survey was conducted. The sample was obtained from the German Chamber of Industry and Commerce and covered companies in 12 different industries. In spring 2010, 290 qualified responses from managing directors or heads of marketing were received. Partial least squares, a broadly accepted variance-based structural equation modeling technique, was used to evaluate the proposed theoretical model (Wold 1985). It has already been used in studies similar to this one (O'Cass et al. 2007, Voola et al. 2010).

No direct relationship between market orientation and company performance could be found. However, market orientation positively impacts learning orientation, which in turn is positively correlated with company performance, and thus an indirect effect could be identified. Hence, it can be concluded that market orientation only becomes effective when a strong learning orientation is present. In addition, key customer focus negatively moderates the path from market orientation to learning orientation, as well as the path from learning orientation to company performance. Hence, it can be inferred that although such a customer strategy is associated with positive company performance, it might hinder organizational learning processes. References available upon request. 